\title{
Rapid recovery of tigers Panthera tigris in Parsa Wildlife Reserve, Nepal
}

\author{
Babu Ram Lamichiane, Chiranibi Prasad Pokheral, Shashank Poudel \\ Dipendra Adhikari, Sailendra Raj Giri, Santosh Bhattarai, Tek RajBhatta \\ Rob Pickles, Rajan Amin, Krishna Prasad Acharya, Maheshinar Dhakal \\ Uba Raj Regmi, Ashok Kumar Ram and Naresh Subedi
}

\begin{abstract}
Information on density and abundance of globally threatened species such as tigers Panthera tigris is essential for effective conservation as well as to evaluate the success of conservation programmes. We monitored tigers in Parsa Widlife Reserve, Nepal, using camera traps, in 2013, 2014 and 2016. Once believed to be a sink for tigers from adjacent Chitwan National Park, Parsa now provides a new hope for tigers. Spatially explicit capture-recapture analysis over 3 survey years revealed an increase in tiger density from 0.78 to 1.38 individuals per $100 \mathrm{~km}^{2}$ from 2013 to 2016 . The tiger abundance was estimated to be seven $(6-13), 11$ (10-16) and $17(17-20)$ in 2013, 2014 and 2016, respectively. Resettlement of communities from the core area, reduced anthropogenic pressure, and improved security have made Parsa Wildlife Reserve a suitable habitat for tigers. Tiger abundance increased considerably within a $5 \mathrm{~km}$ radius of the evacuated village sites, from two in 2013 to eight in 2014 and 10 in 2016. Population turnover has remained moderate $(<30 \%$ per year), with persistence of individuals in multiple years. Dispersing tigers from Chitwan's source population accounted for a large portion (c. $40 \%$ ) of the tigers detected in Parsa. Conservation efforts along with annual monitoring should be continued in Parsa to sustain the increase and monitor the persistence of tigers. The
\end{abstract}

Babu Ram LamichHane* (Corresponding author), Chiranibi Prasad Pokheral, Shashank Poudel, Santosh Bhattarai and Naresh Subedi National Trust for Nature Conservation, Khumaltar, POB 3712, Lalitpur, Nepal

E-mail baburaml@gmail.com, baburam@ntnc.org.np

Dipendra Adhikari, Sailendra Raj Giri and Tek Raj Bhatta Zoological Society of London Nepal Office, Lazimpat, Kathmandu, Nepal

Roв PICKLes Panthera, New York, USA

Rajan Amin Zoological Society of London, Regent's Park, London, UK

Krishna Prasad Acharya Ministry of Forests and Soil Conservation, Department of Forests, Babarmahal, Kathmandu, Nepal

Maheshwar Dhakal Ministry of Forests and Soil Conservation, Sighadurbar, Kathmandu, Nepal

Uba Raj Regmi and Ashok Kumar Ram Department of National Parks and Wildlife Conservation, Kathmandu, Nepal

*Also at: Institute of Cultural Anthropology and Development Sociology, Faculty of Social and Behavioural Sciences, Leiden University, Leiden, Netherlands, and Evolutionary Ecology Group, Faculty of Sciences, University of Antwerp, Antwerp, Belgium

Received 6 March 2017. Revision requested 28 April 2017.

Accepted 26 May 2017. First published online 7 August 2017.
Chitwan-Parsa complex should be managed as a single ecological unit for conserving the Endangered tiger and other wide-ranging species.

Keywords Camera trapping, conservation success, Nepal, Panthera tigris, Parsa Wildlife Reserve, source-sink, tiger population

\section{Introduction}

7 he tiger Panthera tigris, categorized as Endangered on the IUCN Red List (Goodrich et al., 2015), remains in $6 \%$ of its historical range (Joshi et al., 2016). The remaining habitat is not occupied at optimum density because of poaching of tigers, hunting of their prey species and conflict with local communities (Goodrich, 2010; Walston et al., 2010). With the aim to prevent extinction and double the tiger population by 2022, tiger range countries signed the St Petersburg Declaration on Tiger Conservation in 2010 (GTI, 2011), yet tiger populations continue to decline in many countries (Goodrich et al., 2015). Studies show that the remaining habitat can support the global target of doubling the number of wild tigers to 6,000 by 2022 (Wikramanayake et al., 2011) if further degradation of habitat is prevented (Joshi et al., 2016) and core breeding source sites are protected and embedded in larger conservation landscapes (Walston et al., 2010).

Within Nepal, tigers are restricted to five protected areas and surrounding forests in the Terai Arc Landscape in the south of the country, straddling the border with India (Wikramanayake et al., 2004). Of global importance for tiger recovery, the Chitwan-Parsa-Valmiki forest complex of the Terai Arc Landscape was designated a Level I Tiger Conservation Unit, a region of global priority, in 1998 (Wikramanayake et al., 1998). It also constitutes one of the 42 global source sites of tigers (Walston et al., 2010). Despite this global recognition, Parsa had made little contribution to global tiger recovery efforts until recently, with a density of only 0.78 tigers per $100 \mathrm{~km}^{2}$ recorded in 2013 , in contrast to neighbouring Chitwan's 3.84 tigers per $100 \mathrm{~km}^{2}$ (Dhakal et al., 2014). Prey density had also been low in Parsa (5.5 prey individuals per $\mathrm{km}^{2}$ ) compared to Chitwan (62.6 per $\mathrm{km}^{2}$ ) (Karki et al., 2009) as a result of widespread hunting 


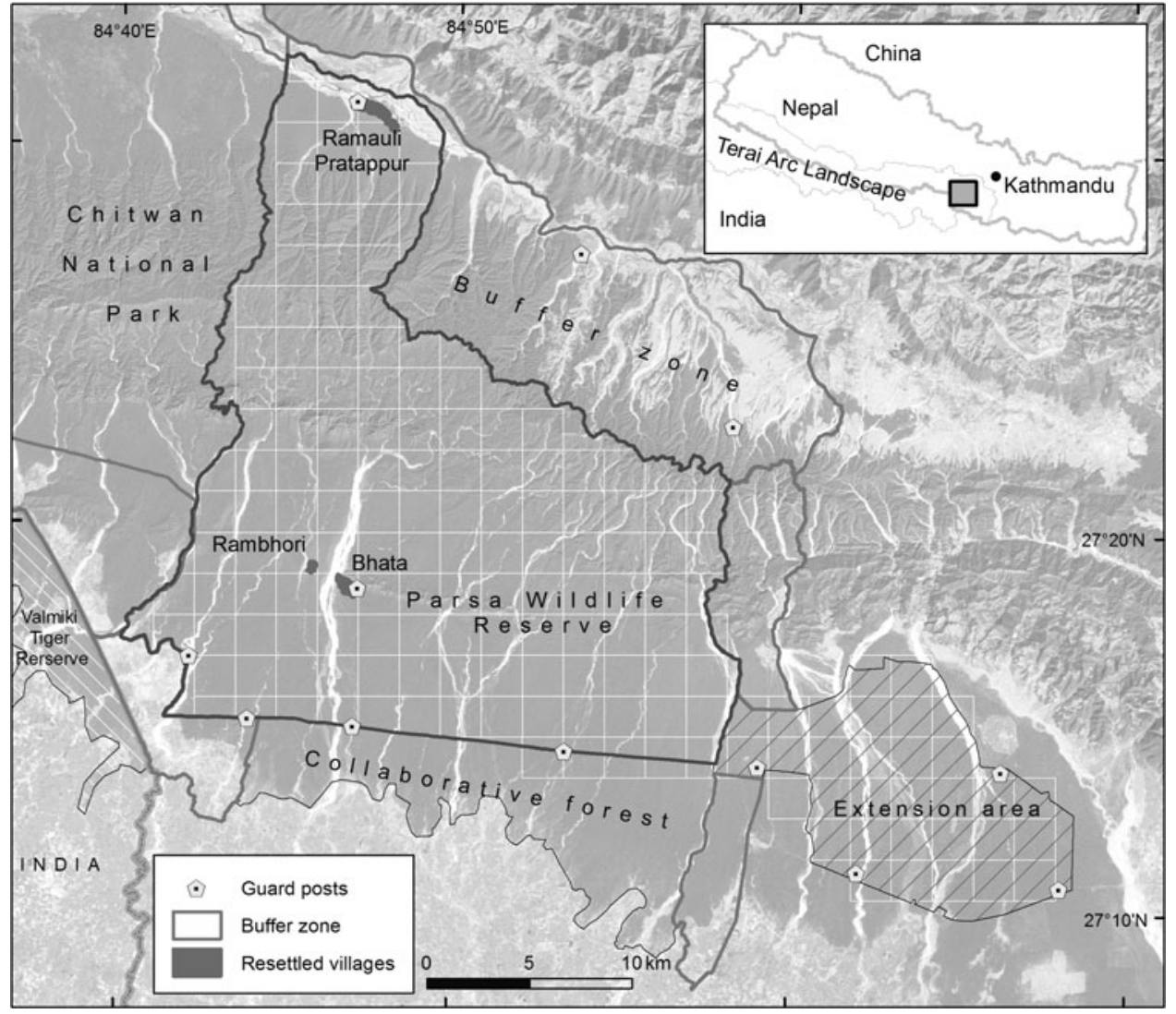

FIg. 1 Parsa Wildlife Reserve (with survey grid) and its buffer zone, and neighbouring Chitwan National Park, Nepal. and habitat degradation through livestock grazing, leading to Parsa being considered the sink to Chitwan's source. There are records of tigers dispersing from Chitwan being poisoned in retaliation by local people (Smith, 1993), or poached for their skin and bones. Dispersal of tigers from high-density areas to lower density areas is a common phenomenon (Harihar et al., 2009; Harihar \& Pandav, 2012). Tigers are territorial, and adult males are known to have large territories encompassing 1-3 females (Sunquist, 1981). Subadults are known to disperse away from the natal area at the age of $19-38$ months to colonize relatively unoccupied areas (Smith, 1993).

In 2010 Nepal committed to doubling the size of its tiger population by 2022, with a goal of 250 adults (GTI, 2013). Parsa is therefore a clear target for conservation interventions to meet the national goal. Here we examine the change in Parsa's tiger population over a 4-year period since significant conservation interventions began, and assess the factors responsible for the change.

\section{Study area}

Parsa Wildlife Reserve is the easternmost protected area of the Terai Arc Landscape. It is connected directly to Chitwan National Park along a $35 \mathrm{~km}$ boundary and is $<2 \mathrm{~km}$ from Valmiki Tiger Reserve's easternmost edge
(Fig. 1). Initially established with an area of $499 \mathrm{~km}^{2}$, Parsa was augmented by the allocation of a $285 \mathrm{~km}^{2}$ buffer zone in 2004, and in 2015 a further $127 \mathrm{~km}^{2}$ was gazetted as core area (hereafter referred to as the extension area; Fig. 1; DNPWC, 2016). Parsa comprises highly porous alluvial substrate and is dominated by the sal forested Churia Hills running from east to west (into Chitwan) in the north of the Reserve. The streams running off the Churia Hills permeate the porous sediment and flow underground, reappearing south of the Reserve and restricting water availability in $>70 \%$ of Parsa throughout the dry months. As well as tigers, Parsa is home to other carnivores, including the leopard Panthera pardus, the dhole Cuon alpinus, the striped hyaena Hyaena hyaena and the golden jackal Canis aureus. A wide range of wild prey species of tigers are found there, including the gaur Bos gaurus, the sambar Rusa unicolor, the nilgai Boselaphus tragocamelus, the spotted deer Axis axis, the barking deer Muntiacus muntjak and the wild boar Sus scrofa (Thapa et al., 2014). Historically, Parsa received less governmental and NGO support for tiger conservation compared to other protected areas in the Terai Arc Landscape. However, since 2012 the Government of Nepal, with technical and financial support from NGOs, has undertaken significant efforts to improve tiger conservation in Parsa (PWR, 2015).

Two settlements, Rambhori Bhata (74 ha, 96 households) and Ramauli Pratappur (116 ha, 377 households), had been located in Parsa prior to the establishment of the Reserve 
(Fig. 1). The local people practised subsistence agriculture, but activities such as livestock grazing, and collection of fodder, fuelwood, timber and other forest products resulted in habitat degradation over a broad area (PWR, 2013). Conflict between local people and wildlife also resulted in retaliatory killings (CNP, 2013). Both communities were resettled voluntarily during 2009-2013. In addition to the village relocations, Parsa's management authorities began a programme of habitat enrichment in 2010, maintaining nine artificial waterholes in the dry season and increasing the area of ungulate grazing by $>50$ ha of grasslands.

\section{Methods}

Camera trapping We set camera traps in a grid of $2 \times 2 \mathrm{~km}$ cells (DNPWC, 2009), deploying a pair of camera traps in each cell during the dry season in 2013, 2014 and 2016. The entire core area of Parsa was covered by 127-138 camera-trap stations. Cameras were active in each station for a minimum of 15 (2013) to 21 days (2014 and 2016). The survey effort was 2,135-3,549 camera-trap days (Table 1). In 2016, $127 \mathrm{~km}^{2}$ of the extension area was covered with an additional 31 camera stations. The Reserve was divided into survey blocks, two in 2014 and three in 2013 and 2016. The blocks were surveyed successively because of the limited availability of camera traps. Prior to deployment of cameras, potential sites where tiger captures and camera safety could be maximized were identified. We positioned the camera traps $45 \mathrm{~cm}$ above ground, perpendicular to, and 5-7 m either side of game trails, forest roads and riverbeds. Pairs of cameras were placed at each sampling point to obtain images of both flanks of photographed individuals to assist in identification. We used Reconyx (Holmen, USA) 500 \& 550, Bushnell (Overland Park, USA) Trophy Cam HD and Panthera (New York, USA) V4 \& $\mathrm{V}_{5}$ cameras. The cameras took three photographs per trigger with no delay, and used white flash to obtain colour images of tigers in low light to help with individual identification.

Estimating population abundance and density Tiger identification was conducted by three independent observers and cross-verified collectively by six or seven observers. We also used ExtractCompare (Conservation Research Ltd, UK) to verify individual tigers identified visually (Hiby et al., 2009). Tiger density and population size were estimated using spatially explicit capturerecapture models in the package secr (Efford, 2016) in $R$ v. 3.0.1 (R Development Core Team, 2015). The default maximum likelihood algorithm with function secr.fit was used to fit the model. To determine the local importance of the former locations of villages for tigers, we subsampled a buffer area of $5 \mathrm{~km}$ radius around the village locations and calculated the number of tigers detected there.

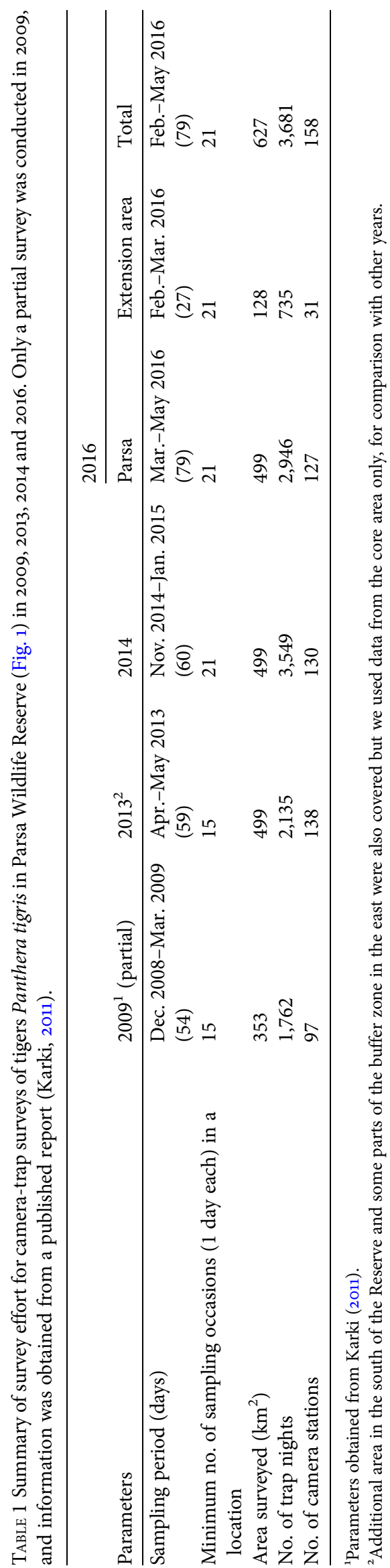


Determining tiger dispersal and persistence We compared the individual tigers detected in 2016 with camera-trap photographs of those recorded in 2014, 2013 and 2009 in Parsa. We also compared all tigers detected in Parsa with tigers recorded in Chitwan National Park in 2013 and its buffer zone in 2015 (Dhakal et al., 2014; CNP, 2015), and in Valmiki Tiger Reserve, India, in 2013 (Maurya \& Borah, 2013; Chanchani et al., 2014).

\section{Results}

Tiger density and abundance During 2013-2016 tiger density in Parsa increased from $0.78 \pm$ SE 0.39 to $1.38 \pm$ SE 0.34 tigers per $100 \mathrm{~km}^{2}$ (Table 2). Five, 10 and 17 individual tigers were detected in 2013, 2014 and 2016, respectively, with an additional two tigers detected in the extension area in 2016. Tiger abundance increased gradually in Parsa during 2009-2016 (Fig. 2).

Evidence of dispersal from Chitwan Over the 3 sampling years a total of 25 adult tigers ( 13 females, 11 males and one of unknown sex) were detected (Table 3). One male and two females were detected in all 3 years, and an additional three individuals (two females and one male) were captured in 2 years (2014 and 2016). Ten new individuals were captured in 2016. Of the 25 individuals recorded, nine were captured first in Chitwan (in 2013 and 2015) and then dispersed to Parsa (in 2014 and 2016). One tiger (Fo4, Table 3) was first captured in Parsa (2014) and dispersed to Chitwan's buffer zone (2015) in the south (Someshwar Hills, contiguous to Valmiki). There was no evidence of tigers dispersing between Valmiki and Parsa.

Recolonization of tigers in evacuated village sites Tigers were confined to a narrow strip in the middle of the Reserve during 2013 (Fig. 3a) but occupied most of the Reserve in the following years (Fig. 3b,c). The 2013 survey failed to detect a single tiger within the $5 \mathrm{~km}$ buffer of Ramauli Pratappur village, which was in the process of relocation at the time. The following year four tigers were detected within the $5 \mathrm{~km}$ buffer, two of which were redetected in the same area in 2016 (Fig. 3). Within the $5 \mathrm{~km}$ buffer surrounding the site of Rambhori Bhata village, which was relocated in 2009, two tigers were detected in 2013, four in 2014 and seven in 2016 (Fig. 3).

\section{Discussion}

Our findings indicate a nearly threefold increase in tiger numbers in Parsa within 3 years. This is a unique scenario of tiger recovery, beyond the potential of natural growth

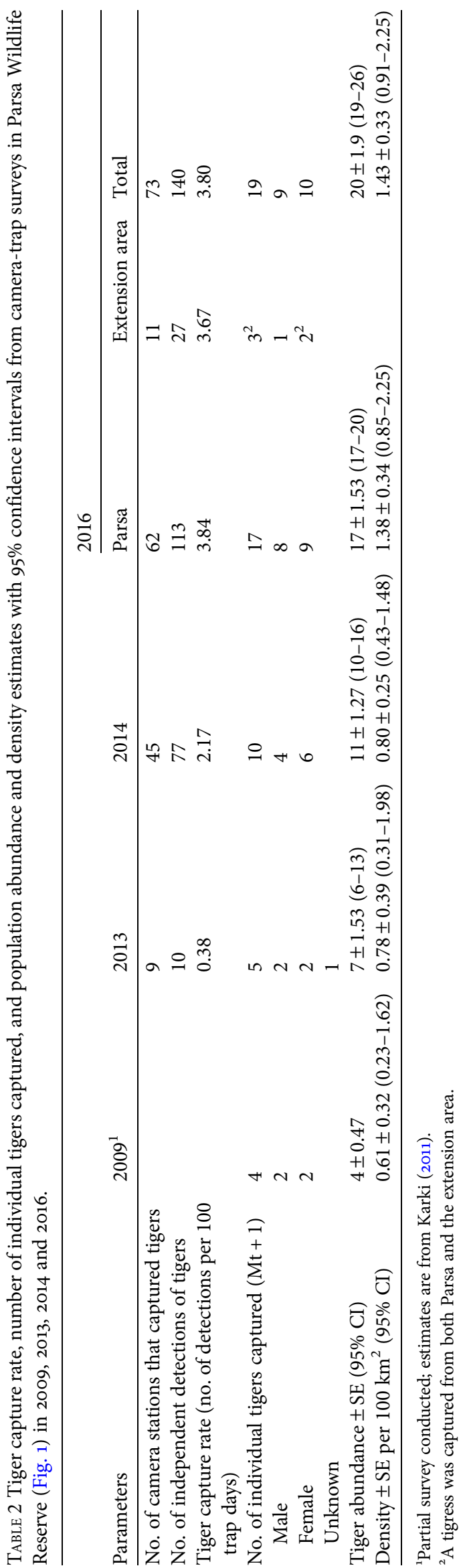




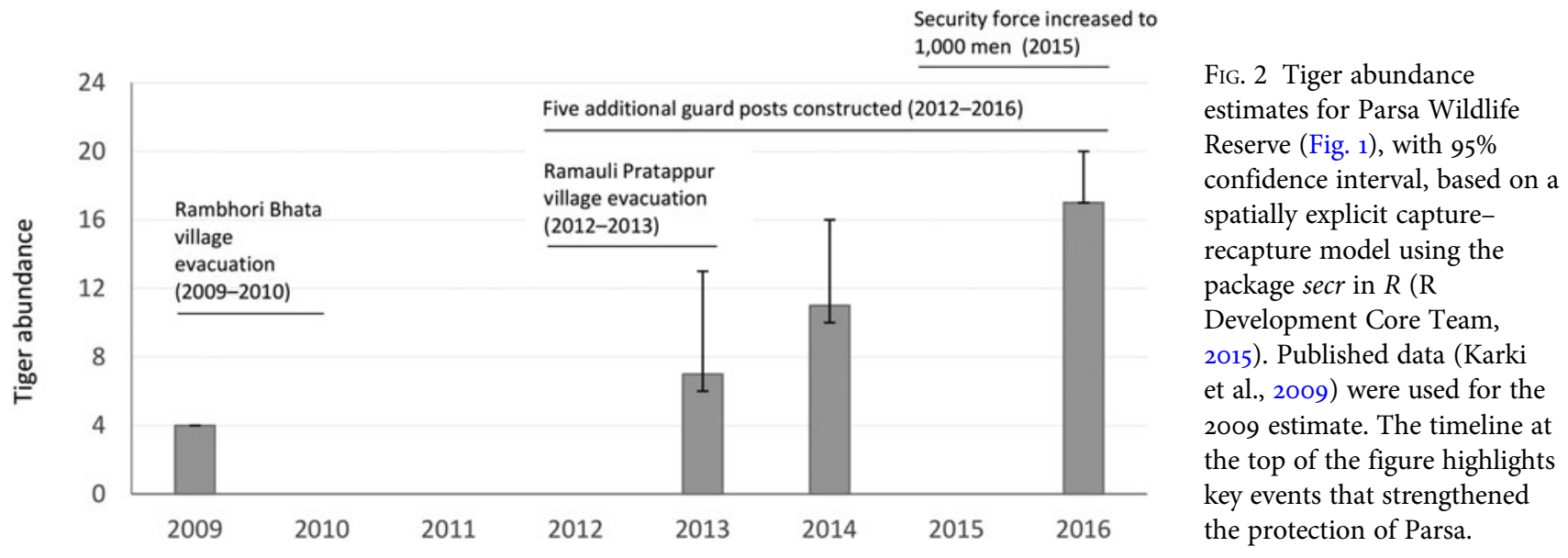

TABle 3 Persistence of individual tigers over 4 years in Parsa Wildlife Reserve and neighbouring Chitwan National Park (Fig. 1). Data from Chitwan in 2016 and data from Parsa in 2015 were not available for cross comparison. Blank cells indicate not surveyed.

\begin{tabular}{|c|c|c|c|c|}
\hline Tiger ID & 2013 & 2014 & 2015 & 2016 \\
\hline$\overline{\mathrm{F} 01}$ & Parsa & Parsa & & Parsa \\
\hline F02 & Parsa & Parsa & & Parsa \\
\hline M01 & Parsa \& Chitwan & Parsa & & Parsa \\
\hline M02 & Parsa & Not detected & & Not detected \\
\hline U01 & Parsa & Not detected & & Not detected \\
\hline F03 & Chitwan & Parsa & Chitwan & Parsa \\
\hline F04 & Not detected & Parsa & Chitwan & Not detected \\
\hline F05 & Chitwan (Cub) & Parsa & & Not detected \\
\hline F06 & Not detected & Parsa & & Parsa \\
\hline M03 & Chitwan & Parsa & & Chitwan \\
\hline M04 & Not detected & Parsa & & Parsa \\
\hline M05 & Chitwan (Cub) & Parsa & & Not detected \\
\hline F07 & Not detected & Not detected & Chitwan & Parsa \\
\hline F08 & Not detected & Not detected & & Parsa \\
\hline F09 & Not detected & Not detected & & Parsa \\
\hline F10 & Not detected & Not detected & & Parsa \\
\hline F11 & Not detected & Not detected & & Parsa (extension area only) \\
\hline $\mathrm{F} 12$ & Not detected & Not detected & & Parsa \\
\hline F13 & Not detected & Not detected & & Parsa (and extension area) \\
\hline M06 & Not detected & Not detected & Chitwan & Parsa \\
\hline M07 & Not detected & Not detected & & Parsa \\
\hline M08 & Not detected & Not detected & & Parsa \\
\hline M09 & Not detected & Not detected & & Parsa \\
\hline M10 & Not detected & Not detected & Chitwan & Parsa (extension area only) \\
\hline M11 & Not detected & Not detected & & Parsa \\
\hline
\end{tabular}

without immigration. In the camera-trap survey of 2013 only five tigers were detected (Dhakal et al., 2014). One of the villages (Ramauli Pratappur) was still in the core area of the Reserve, where a tiger was killed in retaliation after it attacked livestock and people in 2012 (CNP, 2013; Fig. 3a). Tigers recovered quickly, with a total of 17 tigers detected in Parsa, and two others in the extension area, in 2016 (Fig. 3c,d).

Chitwan's source effect was instrumental in the recovery of Parsa's tiger population. Tiger density in Chitwan has remained high and stable in recent years $\left(4.5\right.$ per $100 \mathrm{~km}^{2}$ in
2010, 3.84 per $100 \mathrm{~km}^{2}$ in 2013; Dhakal et al., 2014; Karki et al., 2015), with regular dispersal of subadults beyond the Park's boundary. Of the tigers identified in Parsa during 2013-2016, c. 40\% had been detected previously in Chitwan, including two cubs detected in 2013 and subsequently detected in Parsa in 2014 as young adults (Table 2). Habitat connectivity of continuous sal forest between Chitwan and Parsa facilitated dispersal, particularly of young individuals, leading to a quick recovery. It has previously been suggested that the tigers in both protected areas comprise a single population (Walston et al., 2010). This is supported by our 

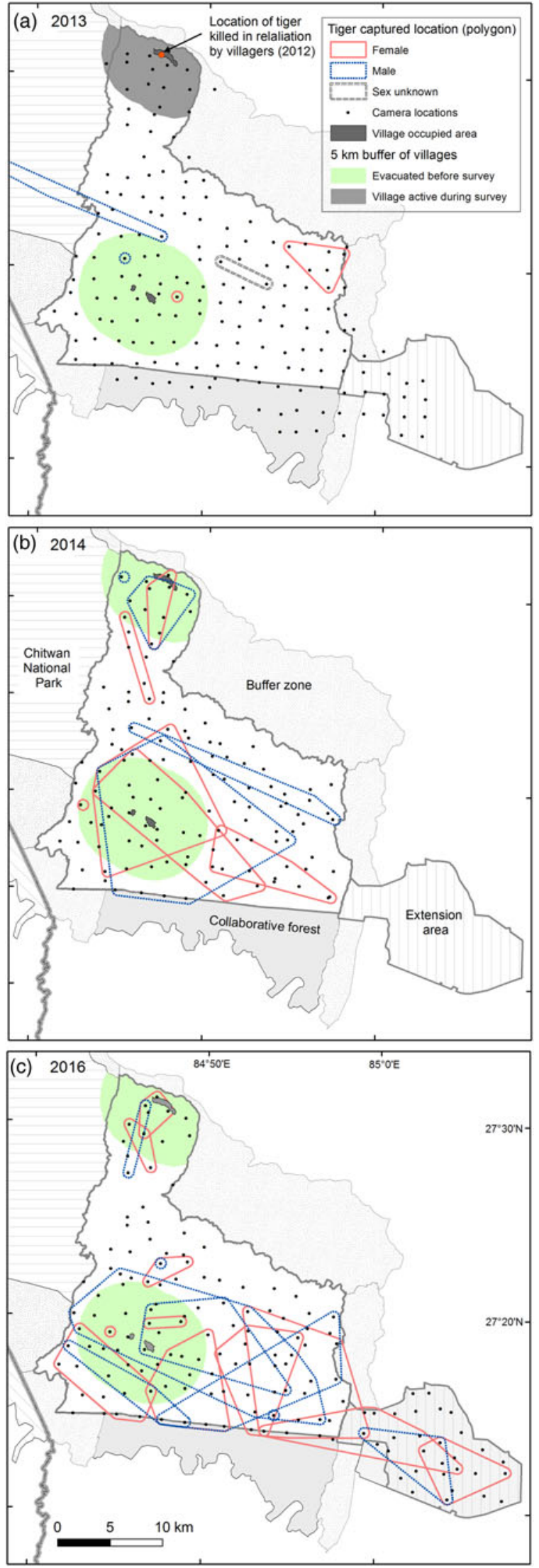

FIG. 3 Camera-trap locations and tiger detection polygons in Parsa Wildlife Reserve, Nepal (Fig. 1) in (a) 2013, (b) 2014 and (c) 2016 . results, which show two-way movement of three individuals between the protected areas, and one individual holding territories that straddle the Park boundary. We therefore recommend managing the two areas as a single entity. Although dispersal of tigers from Chitwan to Parsa is not a new phenomenon, this is the first recording of recolonization of vacant habitat in a sink habitat by substantial numbers of individuals from a neighbouring source in Nepal.

In addition to increasing tiger density in Parsa as a result of the influx from Chitwan, population turnover has remained moderate, and persistence of individuals high. When considered together with the Chitwan dataset, $70 \%$ of tigers identified in 2013 persisted into 2014 and were redetected, and $70 \%$ of the 2014 cohort was redetected in 2016 (Table 3). Tigers are not simply passing through Parsa but are holding territories and breeding. Two females (F1 \& F2) and one male (M1) were detected in all 3 survey years in Parsa. Pugmarks of at least two cubs were also discovered in 2013 and 2014 within $5 \mathrm{~km}$ of the evacuated site of Rambhori Bhata village, indicating that, in addition to immigration, reproduction is now also contributing to the increase in Parsa's tiger population.

The proximate reason for the recovery of tigers in Parsa was predictable, given the high density of tigers in neighbouring Chitwan and the vacation of territory in Parsa following the alleviation of pressures that had historically constrained the increase of tiger numbers there. The recolonization of Parsa can be attributed to two major interventions: resettlement of villages from the core area, and security enhancement in the core area and buffer zone.

\section{Resettlement of villages from the core area}

Our camera-trap results indicate two things. Firstly, tigers started using the vacant areas immediately after evacuation of the villages. Secondly, there is greater intensity of usage by tigers of the land in the locations of the former villages than across the rest of the Reserve, a phenomenon which would have been impossible to achieve had the villages remained. Given the limited availability of water in Parsa, the location of the settlements close to the Reserve's two principal water sources and natural grasslands created competition for this resource between people and wildlife. Conflict with crop-raiding elephants Elephas maximus and cattle-raiding tigers was common (CNP, 2013). The removal of 473 households and their demands on the forest's natural resources substantially reduced local habitat degradation and disturbance in tiger habitat in Parsa's core, and reduced poaching opportunities through reduced access to the Reserve, as has been recorded extensively in India (Karanth \& Madhusudan, 2002; Karanth, 2007).

The conversion of c. 200 ha of farmland and settlement into productive grasslands for ungulate grazing, and the increased access of wildlife to water are not insignificant. Prey 
density increased from 5.5 ungulates per $\mathrm{km}^{2}$ in 2009 (Karki et al., 2009) to 25 ungulates per $\mathrm{km}^{2}$ in 2013 (Dhakal et al., 2014). In 2014 the greater one-horned rhinoceros Rhinoceros unicornis also returned to northern Parsa, grazing on the site of the evacuated villages (DNPWC, 2015).

Rambhori Bhata village was resettled $4 \mathrm{~km}$ south of the Parsa boundary in 2009 and Ramauli Pratappur was resettled c. $2 \mathrm{~km}$ north of Parsa in 2012 and 2013 (PWR, 2013). Resettlement of communities from within protected areas frequently attracts criticism (Schmidt-Soltau \& Brockington, 2007) but studies from Chitwan have shown that people being resettled were positive about the experience (McLean \& Straede, 2003) and benefited socioeconomically in their new location (Dhakal et al., 2011). Households from the two villages within Parsa petitioned for relocation because of the problems they were facing regarding conflict with wildlife and limited access to markets, health and education. All households were granted land allotments in areas outside the Reserve boundary and received financial support from the Government of Nepal for relocation and house construction (PWR, 2013).

\section{Security enhancement in the core area and buffer zone}

Until 2015 security in Parsa was controlled by a company of the Nepal Army comprising c. 200 men in seven guard posts, equating to one man per $2.5 \mathrm{~km}^{2}$. In 2015 the company was upgraded to full battalion strength and shared with Chitwan, increasing the standing force to c. 600 men, or approximately one man per $\mathrm{km}^{2}$ in Parsa. Two additional guard posts were constructed near the northern boundary and three more in the extension area (Dhudhaura, Sahajnath \& Ratanpuri) during 2012-2016. Providing auxiliary support to Parsa's security force, 13 community-based anti-poaching units were formed in 2010, comprising $>200$ local youths from communities around Parsa, who serve voluntarily in controlling illegal grazing, hunting and forest resource extraction, and provide information on poachers and smugglers to the Reserve authority.

The increase in security personnel and expansion of forest guard posts in Parsa from seven in 2013 to nine in 2016 increased protection of tigers and their prey from poaching. Strategically, the placement of the additional guard posts was important, particularly two posts in the northern part of the Reserve, where there had been no patrols previously. The guard posts near the two evacuated village sites secured the new grasslands that evolved there. With a year-round water source, these grasslands are ideal for both ungulates and tigers, and would have been at risk from poaching in the absence of security. The presence of anti-poaching patrols in these areas deterred poaching attempts and facilitated the persistence of recolonizing tigers.

Recovery of tigers has been reported from other parts of Nepal and India (e.g. Panwar, 1982). Tiger and prey populations recovered in Bardia National Park, Nepal, after protection was strengthened there (Wegge et al., 2009). In India's Rajaji National Park in the Western Terai the tiger population increased rapidly, with a high immigration rate following the relocation of Gujjars (the local tribal people) and thousands of their livestock (Harihar et al., 2009).

With the increase in the tiger population, conflict between tigers and communities on the edges of Parsa is likely to rise, as has been reported from Chitwan (Gurung et al., 2008). Preventive and mitigation measures therefore need to be initiated. Although the core area of the Reserve is free of settlements, pressure from grazing, fuelwood and timber extraction continues to encroach from the buffer zone in the north and from the communities south of the $3-5 \mathrm{~km}$ strip of forest in the south of the Reserve that is managed as a collaborative forest. This strip, which is not part of the designated buffer zone, is used by wildlife as a refuge, but they face the threat of poaching and persecution from the communities in the south. Eight of the 17 tigers recorded in Parsa were camera-trapped on the southern boundary of the Reserve in 2016 and we do not know if they went further south into the collaborative forest. Including the collaborative forest in future surveys will provide valuable information about Parsa's tigers. The ongoing work of the Buffer Zone Programme is an essential counterpart to the strengthened security measures within Parsa, reducing the demands of local people on the Reserve's resources through alternative livelihoods, technical innovation and improved governance of communal resources such as the community forest. This integrated conservation effort of strong security coupled with community support should be continued to sustain the recovery of Parsa's tiger population.

Parsa presents a striking example of tiger population recovery and progress towards achieving Nepal's national goal of doubling tiger numbers by 2022 . Following the management interventions undertaken by the Reserve authority and conservation partners in recent years, Parsa has put in place the foundation to facilitate tiger recolonization and population recovery, and illustrates the rapidity with which tiger recovery can occur given the appropriate conditions of controlled poaching, inviolate space and connectivity to a source population.

\section{Acknowledgements}

We thank the Department of National Parks and Wildlife Conservation of the Government of Nepal for giving permission to conduct this research, and the Parsa Wildlife Reserve Office and the National Trust for Nature Conservation for their support in implementing the camera-trap survey. We acknowledge the funding received from ZSL Nepal, Panthera, the USAID Haiyo Ban Program, U.S. Fish \& Wildlife Service and WWF Nepal. 
Leiden University, Netherlands supported the first author during manuscript preparation and Open Access publication. The camera-trap surveys would not have been possible without the tireless effort of field staff, including officers, rangers and game scouts of Parsa Wildlife Reserve, wildlife technicians of the National Trust for Nature Conservation, and student volunteers from Tribhuvan University and Kathmandu University. We acknowledge the contribution of Mr Ashish Bista in data analysis of 2014 surveys and thank Abhishek Harihar and two anonymous reviewers for their valuable comments on the article.

\section{Author contributions}

BRL, NS, CPP, RP and RA designed the study. SP, DA, SRG, SB and URR implemented the fieldwork and collected data. $\mathrm{BRL}, \mathrm{RP}$ and RA analysed the data. All authors wrote and reviewed the article.

\section{References}

Chanchani, P., Lamichhane, B.R., Malla, S., Maurya, K., Bista, A., WA Rrier, R. et al. (2014). Tigers of the Transboundary Terai Arc Landscape: Status, Distribution and Movement in the Terai of India and Nepal. National Tiger Conservation Authority, Government of India, New Delhi, India, and Department of National Park and Wildlife Conservation, Government of Nepal, Kathmandu, Nepal.

CNP (Chitwan National Park) (2013) Annual Report of Chitwan National Park FY 2068/79. Chitwan National Park Office, Kasara, Chitwan, Nepal.

CNP (Chitwan National Park) (2015) Baseline Survey of Tiger and Other Large Mammals in Churia Hills of Someshwar Buffer Zone Area of Chitwan National Park, Nepal. Chitwan National Park Office, Kasara, Chitwan, Nepal.

Dhakal, M., Karki, M., Jnawali, S.R., Subedi, N., Pradhan, N.M. B., Malla, S. et al. (2014) Status of Tigers and Prey in Nepal. Department of National Parks and Wildlife Conservation, Kathmandu, Nepal.

Dhakal, N.P., Nelson, K.C. \& Smith, J.D. (2011) Resident well-being in conservation resettlement: the case of Padampur in the Royal Chitwan National Park, Nepal. Society \& Natural Resources, 24, 597-615.

DNPWC (Department of National Parks and Wildlife Conservation) (2009) Tiger Monitoring Protocol: Tiger (Panthera tigris) and Prey Base Monitoring in the Terai Arc of Nepal. Department of National Parks and Wildlife Conservation, Kathmandu, Nepal.

DNPWC (Department of National Parks and Wildlife Conservation) (2015) Report on National Rhino Count 2015. Department of National Parks and Wildlife Conservation, Kathmandu, Nepal.

DNPWC (Department of National Parks and Wildlife Conservation) (2016) Protected Areas of Nepal. Department of National Parks and Wildlife Conservation, Kathmandu, Nepal.

EFFORD, M.G. (2016) secr: Spatially explicit capture-recapture models. $\mathrm{R}$ package version 2.10.4. Https://CRAN.R-project.org/package= secr.

Goodrich, J.M. (2010) Human-tiger conflict: a review and call for comprehensive plans. Integrative Zoology, 5, 300-312.
Goodrich, J.M., Lynam, A., Miquelle, D., Wibisono, H., Kawanishi, K., Pattanavibool, A. et al. (2015) Panthera tigris. In The IUCN Red List of Threatened Species 2015: e.T15955A50659951. Http://dx.doi.org/10.2305/IUCN.UK.2015-2.RLTS.T15955A50659951. en [accessed 15 June 2017].

GTi (Global Tiger Initiative) (2011) Global Tiger Recovery Program. Global Tiger Initiative Secretariat, The World Bank, Washington, DC, USA.

GTi (Global Tiger Initiative) (2013) Global Tiger Recovery Program: Implementation Plan 2013-2014. Global Tiger Initiative Secretariat, The World Bank, Washington, DC, USA.

Gurung, B., Smith, J.L.D., McDougal, C., Karki, J.B. \& Barlow, A. (2008) Factors associated with human-killing tigers in Chitwan National Park, Nepal. Biological Conservation, 141, 3069-3078.

HARIHAR, A. \& PANDAV, B. (2012) Influence of connectivity, wild prey and disturbance on occupancy of tigers in the human-dominated western Terai Arc Landscape. PLoS ONE, 7(7), e40105.

Harihar, A., Pandav, B. \& Goyal, S.P. (2009) Responses of tiger (Panthera tigris) and their prey to removal of anthropogenic influences in Rajaji National Park, India. European Journal of Wildlife Research, 55, 97-105.

Hiby, L., Lovell, P., Patil, N., Kumar, N.S., Gopalaswamy, A.M. \& Karanth, K.U. (2009) A tiger cannot change its stripes: using a three-dimensional model to match images of living tigers and tiger skins. Biology Letters, 5, 383-386.

Joshi, A.R., Dinerstein, E., Wikramanayake, E., Anderson, M.L., Olson, D., Jones, B.S. et al. (2016) Tracking changes and preventing loss in critical tiger habitat. Science Advances, 2, e1501675.

KARANTH, K.K. (2007) Making resettlement work: the case of India's Bhadra Wildlife Sanctuary. Biological Conservation, 139, 315-324.

Karanth, K.U. \& Madhusudan, M.D. (2002) Mitigating humanwildlife conflicts in southern Asia. In Making Parks Work: Strategies for Preserving Tropical Nature (eds J. Terborgh, C. van Schaik, L. Davenport \& M. Rao), pp. 250-264. Island Press, Washington, DC, USA.

KARKI, J.B. (2011) Occupancy and abundance of tigers and their prey in the Terai Arc Landscape, Nepal. PhD thesis. Forest Research Institute University, and Wildlife Institute of India, Dehradun, India.

Karki, J.B., Jnawali, S.R., Shrestha, R., Pandey, M.B., Gurung, G. \& ThAPA (KARKI), M. (2009) Tigers and Their Prey Base Abundance in the Terai Arc Landscape, Nepal. Department of National Parks and Wildlife Conservation and Department of Forests, Kathmandu, Nepal.

Karki, J.B., Pandav, B., Jnawali, S.R., Shrestha, R., Pradhan, N. M.B., LAmichane, B.R. et al. (2015) Estimating the abundance of Nepal's largest population of tigers Panthera tigris. Oryx, 49, 150-156.

Maurya, K.K. \& Borah, J. (2013) Status of Tigers in Valmiki Tiger Reserve, Bihar, India. WWF-India, New Delhi, India.

McLean, J. \& Straede, S. (2003) Conservation, relocation, and the paradigms of park and people management: a case study of Padampur villages and the Royal Chitwan National Park, Nepal. Society \& Natural Resources, 16, 509-526.

Panwar, H.S. (1982) What to do when you've succeeded: Project Tiger ten years later. Ambio, 11, 330-337.

PWR (Parsa Wildlife Reserve) (2013) A Report of Resettlement of Ramauli Pratappur Village from Parsa Wildlife Reserve. Parsa Wildlife Reserve Office, Adhabhar, Bara, Nepal.

PWR (Parsa Wildlife Reserve) (2015) Annual Report of Parsa Wildlife Reserve FY 2071/72. Parsa Wildlife Reserve Office, Adhabhar, Bara, Nepal.

R Development Core Team (2015) R: A Language and Environment for Statistical Computing. R Foundation for Statistical Computing, Vienna, Austria. Https://www.R-project.org/. 
Schmidt-Soltau, K. \& Brockington, D. (2007) Protected areas and resettlement: what scope for voluntary relocation? World Development, 35, 2182-2202.

Sмiтh, J.L.D. (1993) The role of dispersal in structuring the Chitwan tiger population. Behaviour, 124, 165-195.

Sunquist, M.E. (1981) The Social Organization of Tigers (Panthera tigris) in Royal Chitawan National Park. Smithsonian Institution Press, Washington, DC, USA.

Thapa, K., Shrestha, R., Karki, J., Thapa, G.J., Subedi, N., Pradhan, N.M.B. et al. (2014) Leopard Panthera pardus fusca density in the seasonally dry, subtropical forest in the Bhabhar of Terai Arc, Nepal. Advances in Ecology, 2014, http://dx.doi.org/10. 1155/2014/286949.

Walston, J., Robinson, J.G., Bennett, E.L., Breitenmoser, U., DA Fonseca, G.A.B., Goodrich, J. et al. (2010) Bringing the tiger back from the brink-the six percent solution. PLoS Biology, 8(9), e1000485.

Wegge, P., Odden, M., Pokharel, C.P. \& Storaas, T. (2009) Predator-prey relationships and responses of ungulates and their predators to the establishment of protected areas: a case study of tigers, leopards and their prey in Bardia National Park, Nepal. Biological Conservation, 142, 189-202.

Wikramanayake, E., Dinerstein, E., Robinson, J.G., Karanth, U., Rabinowitz, A., Olson, D. et al. (1998) An ecology-based method for defining priorities for large mammal conservation: the tiger as case study. Conservation Biology, 12, 865-878.

Wikramanayake, E., Dinerstein, E., Seidensticker, J., Lumpkin, S., Pandav, B., Shrestha, M. et al. (2011) A landscape-based conservation strategy to double the wild tiger population.

Conservation Letters, 4, 219-227.

Wikramanayake, E., McKnight, M., Dinerstein, E., Joshi, A., Gurung, B. \& SMith, D. (2004) Designing a conservation landscape for tigers in human-dominated environments. Conservation Biology, 18, 839-844.

\section{Biographical sketches}

BABU RAm LAMichHANE is interested in the application of geographical information systems (GIS) for wildlife management, and humanwildlife interactions. Chiranjibi Prasad Pokheral is interested in large carnivore biology and interspecies interactions. SHASHANK POUdel is interested in conservation communication. Dipendra ADHIKARI is interested in small mammals. SAILENDRA RAJ GIRI is interested in applications of GIS and remote sensing in wildlife conservation. Santosh Bhattarai is interested in herpetology. Tek Raj Bн а тт А is involved in development and implementation of conservation projects. Rов PICKLES specializes in tiger monitoring using camera traps. RA J AN AMIN specializes in the conservation of Asian and African grassland and forest ecosystems. KRISHna PRASAD ACHARYa is interested in resolving human-wildlife conflicts. MAHESHWAR DHAKAL is involved in policy analysis of protected areas. UBA RAJ REGMI has served as manager of Parsa Wildlife Reserve and other protected areas in Nepal. Asнo к Kumar Ram is involved in geospatial modelling of wild elephants in Central Nepal. NARESH SUBEDI is interested in the ecology of rhinoceroses and invasive species. 